\title{
The Vocal Instructional Design from Student-based Education Concept
}

\author{
Xu Ning \\ Dongchang College of Liaocheng University, Shandong, Liaocheng 252000
}

Keywords: student-based education concept; vocal music; instructional design

\begin{abstract}
The vocal music is one of the important contents of school education, which raises the students' music accomplishment, enhances the artistic percipient and the effective way of expression creativity, and has the vital significance in regarding to set up student's aesthetic standard and form the noble humanities spirit. Given that many music teaching ignore the music aesthetic laws, correcting the music lesson knowledge into music lessons or music analysis class phenomenon becomes the premise of vocal music teaching. Therefore, music teachers are required to adhere to the principles of student-based education idea, on the basis of the principles of vocal music teaching and accurate positioning of the teaching goal, motivate the students' association and thinking, fully use the multimedia auxiliary teaching means to create teaching situation, cooperation and exchange activities, and organize group to give play to students' creativity and imagination, so as to realize the sublimation of the spirit and rational understanding, the improvement of the aesthetic psychology and thinking leap.
\end{abstract}

\section{Introduction}

Vocal music is an important content of school education, is to cultivate students' music accomplishment, an effective way to improve art appreciation and creativity, to set up the student's aesthetic view, the formation of noble humanistic spirit is of great significance. To arouse the enthusiasm of the students to music art through the process of vocal music teaching, form of vocal music and the expression of the most basic literacy, to cultivate students' noble sentiment, introducing students to the true life, is the real purpose of teaching.

\section{Vocal Education Requests from Student-based Educational Concept}

Student-based education is to advocate quality education in our country, and in constant practice, exploration and innovation produced and developed a kind of education idea. The original concept of the education derived from the Czech famous educators to boast of the United States and New Zealand, in his 17th century education discourse. There will be a discussion related to: "Find out a method of education, so you can make teachers teach less, but students can learn more; which can make school less blatant, disgust and unproductive Labour, unique leisure, pleasure and solid progress." To boast of the United States and New Zealand's view describes the teaching methods of an important shift is that it is necessary to integrate education teaching load by schools and teachers and to students. And causes the student through teacher's function to stimulate, by student's interest, the enthusiasm as well as the wisdom potential carries on the study and the knowledge acquisition on own initiative, realizes school, teacher and the student three between harmony joyful conditions. Student-based education theory researchers Guo Si said: "education is rely on person's special mental process of life activity, it eventually or basically consists of a integrity, active and growth (innovation) of his life." ${ }^{[1]}$ Here, Professor Guo clearly indicated that education should be a manner, that is, the return to education, respect for the education of the natural properties of the nature of the problem. It is not difficult to see that in more cases, we do it for the learner to create an external environment for learning, develop an external learning mechanisms, and that these things do the better, and the quality of education, in fact it has relative to the neglect of the learner's own inherent characteristics, laws and requirements. Student-based education idea can say it is for this neglect and ignore the warning, is to "teacher education" transformation "student-based education". 
Since the concept of student-based education attaches great importance to the students' subjectivity of life, the law of cognitive development and individual development and creation, so in vocal music teaching in teachers' teaching strategy must be designed around the students, It is necessary to respect from the students' cognitive psychology and law, but also to meet the students' psychological desire and objective requirements, and straight to improve students' quality and the human spirit of educational goals. Vocal music teaching, therefore, must make the music stream flows through the students' heart, nourish the soul of students, student's thought, the role of teacher is the selection, create, organize, and prompt, inspire and evaluation, not the kitchen instead of.

\section{The Principles of Vocal Music Teaching from Student-based Educational Concept}

According to Kant, appreciation is a kind of ability of beauty. learning vocal music is a process of judgment of music art beauty, vocal music teaching is to cultivate students' ability of an activity. Therefore, the vocal music teaching is use certain music art or music work, and carries on the performance through certain media method to it, causes the student to enter gradually to music work feeling, the experience, the appreciation and the distinction spiritual activity process. ${ }^{[2]}$ Either from the perspective of the level of artistic activities, or from the purpose of music teaching, vocal music is a higher target. Therefore, vocal music works for music teaching should be set high goals, rather than simply enjoy music and learn music knowledge.

Aylen · Copeland has said: "If you must understand music well, again compared to has not listened attentively to music importantly."Obviously, listens attentively is the feeling becomes aware, comprehends music the premise and the foundation. Listens attentively is human's sense of hearing under the outside sound stimulation one kind of function reflection and the physiological intuition process, But not human physiological reaction has been intuitive, person's memory, emotion and thinking is in the music of sensory stimuli to the brain to imagine together, thus draw once had the emotional experience. Therefore, two crucial essential factor of the vocal music process is the collision and the fusion which music expresses the force and the human thought.

Simply put, the appreciation of music is a process of a person to listen to and understand the process, listening to music is the theme of the hearing outside the physiological and psychological received induction process. This all can achieve to any sense of hearing normal people; The understanding is the cerebrum to music tonality, the rhythm and the timbre imagination, the experience and the thought process, This actually is much more difficult to very many people, this explains the vocal music importance to the essential accomplishment of the connoisseurship music, but this accomplishment are exactly lack in very many institutes of human. Whether then some accomplishment do raise like this? The essential method is must the conformity and the vocal music related several essential factors.

\section{The Vocal Music Teaching Design from Student-based Educational Concept}

As a result of today's community arts development, commercialization and secularization tendencies, all kinds of so-called popular music filled life. The distinctive consciousness of the young students are insufficiency, and the situation in the connoisseurship ability are not strong, the beautiful clowns who cannot distinguish music work on their own initiative, esthetic orientation also with difficulty to correct. For this reason, the teachers' vocal music teaching materials must not be vague, but must adhere to the following principles: First, it is necessary to select the correct ideological character of the music. Second, it is necessary to select a high artistic music. Once more, they must choose the materials that can stimulate the students to inquire into wants with the creativity work. Only then can it promote the students' vocal music and the practice union. Moreover, they also must take the following music work, such as the classical, the public, traditional and modernity and so on.

From the word meaning understood "listens attentively to" two characters, it covers three meanings: One is to listen carefully, two is to listen attentively, three is to listen repeatedly. Not only such three enhanced gradually listens attentively to the link to increase quantity which the student 
listened, but also improved the quality which the student listened; The responsibilities of the teachers will no longer be in order to speak with listening, and certainly not to speak on behalf of the hearing, but guided the students how to listen to. All revolve around the students to listen to, and crossed the two steps: The first step is through the language of music of high and low tones, fast-paced slowly, the sound quality sound and feel the mood of the music, and gradually build up the music sound legal knowledge and experience; The second step is through the text content such as music title, description, the expression of music imagination and legend, in order to enhance the expression of music thinking methods of emotional experience and understanding ability, cultivate music flowing consistent patterns of thinking.

Schopenhauer Arther believed, music can completely reappear and express the world. But the way that music expresses the world is not language, nor use the picture color. Music gives human more imagination space, which neither the language and writing nor the drawing color can compare with. The difference is that students initially did not have the experience of music appreciation, so how secondary students faster imagine music expression of the world, should be another important aspect of the teachers teaching design.

\section{References}

[1] Anonymous. This student-based education concept significance in understanding [EB/OL]. http://www.360doc.com/content/10/0824/23/2556296_48550621.shtml20100824

[2] Hu Sangwu. Slightly in high school singing "student-based" in classroom teaching mode [J]. Jiamusi education journal. 2013(4):132. 